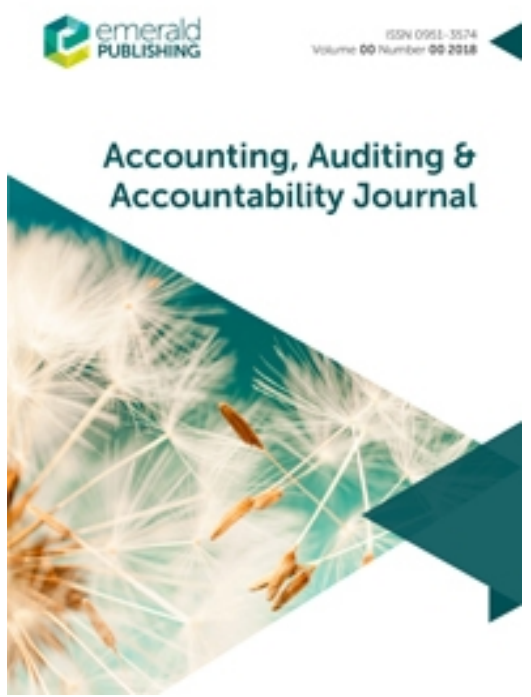

\title{
Examining the accounts of oil spills crises in Nigeria through sensegiving and defensive behaviours
}

\begin{tabular}{|r|l|}
\hline Journal: & Accounting, Auditing \& Accountability Journal \\
\hline Manuscript ID & AAAJ-12-2018-3794.R2 \\
\hline Manuscript Type: & Research Paper \\
\hline Keywords: & $\begin{array}{l}\text { oil spills, sensegiving, multinational oil corporations, Nigeria, blame } \\
\text { avoidance defensive behaviours, Social and environmental narratives } \\
\text { and accountability }\end{array}$ \\
\hline \multicolumn{2}{|l}{} \\
\hline
\end{tabular}

\section{SCHOLARONE \\ Manuscripts}




\title{
Examining the accounts of oil spills crises in Nigeria through sensegiving and defensive behaviours
}

\begin{abstract}
Purpose: The paper examines how oil multinational companies (MNCs) in Nigeria framed accounts to dissociate themselves from causing oil spills.

Design/methodology/approach: We utilised data from relevant corporate reports, external accounts and interviews, and used sensegiving with defensive behaviours theoretical framing to explore corporate narratives aimed at altering stakeholders' perceptions.

Findings: The corporations gave sense to their audience by invoking scapegoating blame avoidance narrative in attributing the cause of most oil spills in Nigeria to outsiders (sabotage), despite potentially misclassifying the sabotage-corrosion dichotomy. Corporate stance was reinforced through justifying narrative, which suggested that multi-stakeholders jointly determined the causes of oil spills, thus portraying corporate accounts as transparent, credible and objective.
\end{abstract}

Practical implications: With compensation to oil spills' victims only legally permitted for nonsabotage-induced spills alongside the burden of proof on the victims, the MNCs are incentivised to attribute most oil spills to sabotage. On policy implication, accountability would be best served when the MNCs are tasked both with the burden of proof and a responsibility to demonstrate their transparency in preventing oil spills, including those caused by sabotage.

Research implications: The socio-political dynamics in an empirical setting affect corporate accounts and how those accounts appear persuasive, implying that such contextual factors merit consideration when evaluating corporate accounts. For example, despite contradictions in corporate accounts, corporate attribution of oil spills to external factors appeared persuasive due to the inherently complicated socio-political dynamics.

Originality/value: Crisis situations generate multiple and competing perspectives, but sensegiving and defensive behaviours lenses enrich our understanding of how crisis-ridden companies frame narratives to alter stakeholders' perceptions. Accounts-giving therefore partly satisfies accountability demands, and acts as sensegiving signals aimed at reframing/redefining existing perceptions.

Keywords: Social and environmental narratives and accountability; oil spills; sensegiving; blame avoidance defensive behaviours; multinational oil corporations; Nigeria. 


\section{Introduction}

Prior studies have examined corporate disclosures in relation to oil spills, particularly the British Petroleum (BP) Gulf of Mexico oil spill of 2010 (Arora and Lodhia, 2017; Botes and Samkin, 2013; Helflin and Wallace, 2017; Summerhays and de Villiers, 2012) and Exxon Valdez oil spill of 1989 (Deegan et al., 2000; Patten, 1992; Walden and Schwartz, 1997). Incidentally, both incidents occurred in the US. While they have attracted public criticisms, the corporate narratives associated with them have also generated scholarly commentaries. Similar incidents are a commonplace in Nigeria, yet the examination of the attendant corporate disclosures has not received the deserved research attention. This research focuses on Nigeria due to its unique long history of perennial and widespread oil spills with pervasive negative social and environmental impacts, which earned Nigeria the tag of the global capital of oil pollution (BBC, 2010). Oil multinational corporations (MNCs) whose operations are linked to this pollution, like in other countries, have come under intense criticisms resulting in a myriad of corporate disclosures (Buccina et al., 2013; Egbon et al., 2018; Pupovac and Meorman, 2017). However, the uniqueness of oil spills in Nigeria relates to their regularity, widespread as well as the contestation and blame game that follow them. Given this uniqueness and the accountability tension created by the blame game, we consider it important to explore corporate accounts on oil spill incidents in Nigeria, which are not only perennial in occurrence with pervasive negative environmental impacts but also highly contested (Denedo et al., 2018, 2019; European Parliament, 2011; Pupovac and Meorman, 2017). The blame game has its root in the fact those oil spills have been caused by internal (corporate) and external (third party) factors, but the actual proportion caused by each factor is masked by ambiguity. Such ambiguity creates the tension for a blame game, which has both policy and practical implications. For example, oil spills have largely stimulated corporate-community conflicts in the Niger Delta region of Nigeria (Babatunde, 2020), particularly as the alleged causes determine whether the victims are entitled to compensation (Adewale, 1989). Moreover, the contentious nature of oil spills in Nigeria has had implications for the discharge of the related responsibility and accountability.

While prior studies on corporate accounts involving oil spill incidents have largely focused on one-off incidents (Arora and Lodhia, 2017; Botes and Samkin, 2013; Deegan et al., 2000; Helflin and Wallace, 2017; Patten, 1992; Summerhays and de Villiers, 2012; Walden and Schwartz, 1997), this study focuses on a context where oil spills regularly occur. Recurring oil spills create negative environmental impacts and instigate negative perceptions from stakeholders towards the indicted companies. Following the contestation surrounding the recurring and pervasive oil spill incidents in Nigeria, the purpose of this paper is to explore how oil multinational companies (MNCs) in Nigeria strategically framed accounts to dissociate themselves from causing the oil spills by reframing the general view that the oil spills are caused by the negligent acts of the oil companies. Such strategically redefined or reframed narratives are apparently intended to manage stakeholders' perceptions and deflect negative consequences in relation to the causes of the oil spills. In framing the nature of corporate accountability in relation to the alarming corporation-linked oil spill environmental crisis in Nigeria, this paper adopted the lenses of sensegiving and blame avoidance defensive behaviours to examine how the MNCs employ narratives to favourably alter stakeholders' perceptions on the contested causes of oil spills. Boin et al. (2009), for example, argue that crisis usually generates narratives and counter-narratives in relation to its severity, causes, responsibility for its occurrence, while those contesting it struggle to impose their views as the dominant narratives. Sensegiving lens thus provides an understanding within the contexts 
of crisis and change (Drori and Ellis, 2011; Gilstrap et al., 2016; Levine Daniel and Eckerd, 2019) as companies adopt sensegiving mode of communication during crises (Wehmeier and Schultz, 2011). As negative corporate incidents naturally provoke negative public reactions, companies are under pressure to mobilise defensive accounts as strategic tools to avoid blame and to favourably alter stakeholders' perceptions. While companies frame their narratives to persuade their audience about a reality, their accounts are only a partial representation of that reality (Laine and Vinnari, 2017; Moerman and van der Laan, 2015; Tregidga, 2017). Consequently, the paper draws on corporate accounts, independent external accounts and interviews to provide multiple perspectives on the causes of oil spills in Nigeria (Gray, 2013; Parker, 2008) with the aim of balancing views and spotting gaps in the corporate accounts (Adams, 2004; Dey, 2003; Ruffing, 2007; Tregidga, 2017).

We adopt a qualitative case study approach with a focus on the big-five oil MNCs (Chevron, Eni, ExxonMobil, Shell and Total) in Nigeria whose operations have been largely linked to the oil spill incidents. The perennial and widespread nature of the oil spills warrants the calls to hold these companies accountable for their actions and impacts (Belal et al., 2013; Buccina et al., 2013). Whereas oil spills, gas flaring and waste discharge are the principal pollution of oil companies in Nigeria, oil spills are highly controversial as they potentially originate from sabotage (actions of third parties) and corporate negligence (European Parliament, 2011). In Nigeria, these two broad causes of oil spills have serious implications for their control and elimination, as well as determining who is culpable, responsible and accountable for them. Consequently, corporate and external stakeholders' narratives have centred on what/who causes the oil spills and who should be held accountable for them. Such controversy and the attendant public perceptions portend legitimacy threat for the implicated oil companies (Bebbington et al., 2008; Pupovac and Moerman, 2017).

Furthermore, it is noteworthy that the causes of oil spills and the attendant clean-up and environmental remediation are predominantly the dual subjects of oil spill controversy in Nigeria (Egbon et al., 2018; UNEP, 2011), but we have focused on the narratives involving the causes of oil spills for two reasons. First, the exacerbated controversy of how many oil spills are caused by corporate actions or sabotage largely fuels the perennial corporatecommunity conflicts vis-à-vis agitations regarding compensation. Second, it will provide insights on the ambiguity surrounding the causes of oil spills in Nigeria and the implications for accountability. As such, the paper provides insights on the accountability practices of environmentally sensitive industries in developing economies - specifically Nigeria, where the environmental pollution is both perennial and pervasive. From the empirical analysis, the corporations gave sense to their audience by invoking scapegoating blame avoidance narrative in attributing the cause of most oil spills in Nigeria to outsiders (sabotage), despite potentially misclassifying the sabotage-corrosion dichotomy. Corporate stance has been reinforced through justifying narrative, which suggested that the causes of oil spills were jointly determined by multi-stakeholders, thus portraying the corporate accounts as transparent, credible and objective. This study contributes to the wider literature of corporate accountability through the lenses of sensegiving and defensive behaviours to provide insights on how multiple corporations employ blame avoidance narratives to influence stakeholders' perceptions in the face of detestable outcomes or incidents. More specifically, it contributes to prior studies on corporate disclosures involving oil spill incidents by extending the level of resolution beyond a single company to multiple corporations which have contemporaneously mobilised strategic narratives as persuasive signals to influence stakeholders' perceptions over recurring negative incidents. 
The remainder of this paper is organised as follows. We provide a review of corporate disclosures involving negative incidents and then discuss the analytical lenses of sensegiving and defensive behaviours. Next, we discuss the data and methods and then present the analysis of empirical evidence followed by the discussion of findings. Finally, we provide some concluding remarks.

\section{Review of prior studies on corporate disclosures on major negative incidents}

Several studies have examined corporate disclosures with respect to two major US oil spills following widespread media coverage. These oil spill incidents widely covered by prior studies are the British Petroleum (BP) Gulf of Mexico oil spill of 2010 (Arora and Lodhia, 2017; Botes and Samkin, 2013; Helflin and Wallace, 2017; Summerhays and de Villiers, 2012) and Exxon Valdez oil spill of 1989 (Deegan et al., 2000; Patten, 1992; Walden and Schwartz, 1997). While those incidents attracted public criticisms, the narratives associated with them have generated scholarly commentaries. But oil spills in Nigeria are both a commonplace and household phenomenon in the Niger Delta communities where they occur, which makes BBC (2010) to nickname Nigeria as the global capital of oil pollution. Hence, the corporate narratives in connection with the widespread oil spills in the fragile Niger Delta wetland deserve in-depth investigation especially as the indicted corporations are still able to carry on their operations with impunity. This paper is thus designed to explore an important aspect of the oil spill debacle in Nigeria, particularly the narratives relating to its controvertible causes. Primarily, this section reviews prior studies on oil spill incidents to provide context for the paper and its contribution to the voluntary disclosure and accountability literature.

Botes and Samkin (2013) examined BP's communicative posture in dealing with the legitimacy crisis and stakeholders' criticisms instigated by the Gulf of Mexico oil spill. They argued that BP employed different strategically compelling narratives to manage the perceptions of its stakeholders because of the potentially damaging consequences the crisis generated. Such tactics (apologia) included denial, counterattack, differentiation and apology, which enabled the company to partly shift their blame (see Botes and Samkin, 2013 for detailed discussion). More recently also, Arora and Lodhia (2017) examined how BP deployed social and environmental disclosures to manage its reputation risk associated with the Gulf of Mexico oil spill crisis. Drawing on reputation risk management, they observed that BP actively used its website to disclose social and environmental information to manage the crisis by deploying different image restoration strategies due to the potentially damaging impact of the crisis on its reputation (Bebbington et al., 2008; Benoit, 1997). Both studies suggest that the oil spill posed reputational and legitimacy threats to the company, which instigated corporate narratives to alter stakeholders' adverse perceptions and reactions.

Also, Summerhays and de Villiers (2012) examined whether the BP oil spill engendered increased disclosures in the annual reports of other large companies in the oil industry because of its potential legitimacy threat on the industry. By evaluating the companies against three disclosure strategies (image enhancement, disclaimer and deflection), they find evidence that the companies increased their environmental disclosures, mostly positive disclosures compared to neutral or negative ones, as an image enhancement strategy to enable them to regain threatened legitimacy. Investors may negatively react to companies that fail to disclose more environmental information (although the information may be symbolic rather than substantive) in the industry that experienced a disaster because of the perceived future disaster costs and potential exposure to greater regulatory risk (see Heflin and Wallace, 2017). Deegan et al. (2000) also find evidence of corporations making more 
voluntary information disclosures in their annual reports following a disaster incident linked to a company within their industries compared to periods preceding the incident. As Exxon Valdez incident was one of the incidents explored by Deegan et al. (2000), and similar to Summerhays and de Villiers (2012; see also Patten, 1992), they find evidence that companies in the Australian oil industry increased their environmental information disclosure after the Exxon Valdez incident in the US.

Other studies have equally examined growth in corporate disclosures following negative incidents. For example, Coetzee and van Staden (2011) find increase in disclosures by large mining firms in South Africa following mining accidents in reaction to legitimacy threat. Similarly, Walden and Schwatz (1997) examine changes in corporate environmental disclosures in four industries after Exxon Valdez oil spill and they find increased environmental disclosures across the four industries. With empirical evidence suggesting that companies operating in the same industry (including other comparably sensitive industries) will increase their environmental disclosures due to the perceived legitimacy threat when one of them caused a major negative environmental incident, it is realistic to expect the implicated company to provide greater information in relation to the incident as its legitimacy is apparently more threatened. In Nigeria where oil spills are widespread and recurring, the companies whose operations are linked to them will feel more pressured to alter their stakeholders' perceptions in their favour given the incidents' media publicity. However, the focus of this study is not on the amount of disclosure, but on the strategic use of persuasive disclosures to alter stakeholders' perceptions.

Following wide media coverage given to environmental crises (Deegan et al., 2000), stakeholders are likely to react negatively towards the companies linked to those crises. For example, Carberry et al. (2018, p. 121) argue that "investors will be more likely to react negatively to misconduct when the media focuses more attention on it, and presents clear and credible information that misconduct occurred, that the firm was responsible for it, and that it was the result of deeper organizational problems." This scenario increases the pressure on such companies to provide their side of the story. Hence, companies linked to an environmental disaster increase their disclosure of positive news following the crisis to enhance how stakeholders view them (Summerhays and de Villiers, 2012). Due to the negative consequences people may suffer for being linked to a discredited phenomenon, they are incentivised to use evidence to distance themselves from it. For example, Detzen and Hoffman (2018) demonstrate how two eminent German academics use narratives with accumulated evidence to dissociate themselves from the stigmatised Nazi Regime following the World War II because of how it would negatively affect them.

Furthermore, Pupovac and Moerman (2017) examine Shell's hybrid account, a response letter, which demonstrates how the company uses self-account as a rhetorical accountability device in relation to oil spill in its Nigeria's operations. Underlying the company's narrative is the portrayal of itself as a responsible entity (Nwagbara and Belal, 2019) that manages the oil spill incidents with the associated curtailment, clean up, compensation payments to victims and environmental remediation in Nigeria.

When organisations know that stakeholders expect environmentally responsible behaviour from them, they tend to align their narratives to make them look so to their audience (Cho et al., 2018). Increasingly, corporations use social and environmental accounting (SEA) reports in the public domain to formally communicate to or dialogue with their shareholders and other stakeholders (Botes and Samkin, 2013; Cho et al., 2018; Du and Vieira, 2012; Pupovac and Moerman, 2017). Specifically, companies use channels such as 
news media, websites, corporate social responsibility (CSR) reports, sustainability reports, etc. to disseminate their accounts (Du and Vieira, 2012). These accounts can be as persuasive tools to control the conversation involving controversial crises such as oil spills. Prior studies have shown that companies can use SEA reports to project a good self-image before their audience (Bebbington et al., 2008) and control the conversation (Livesey and Kearins, 2002; Pupovac and Moerman, 2017). Hence, this paper's focus on oil spill environmental crisis in Nigeria to explore how the oil MNCs strategically manage their stakeholders' perceptions and forestall negative reactions by framing narratives to dissociate themselves from causing the widespread oil spills.

\section{Theoretical frameworks}

Contestations surround the perennial oil spills linked to the operations of oil MNCs in Nigeria, thus meriting a research examining how these MNCs strategically frame accounts to dissociate themselves from causing the oil spills by reframing the general perception that corporate negligence was to blame. With insight from Horbach et al. (2019) and Ploeger and Bisel (2013), the corporations' strategically reframed or (re)created narratives aimed at influencing stakeholders' perceptions and deflecting negative consequences accompanying negative incidents are engendered to give sense to the stakeholders by the instrumentality of defensive communicative strategies. In our study, giving sense and mobolising defensive communicative strategies are pivotal for the corporations in reframing or recreating the images stakeholders have of them due to the oil spill incidents. As such, we adopt the sensegiving lens to explore the case companies' use of narratives to influence the perceptions of their audience as the companies dissociate themselves from causing most of the widespread oil spills linked to their operations. We equally draw on blame avoidance defensive behaviours by Ashforth and Lee (1990) to frame and tease out how the implicated companies mobilise accounts in a sensegiving fashion to manage stakeholders' negative perceptions and douse the attendant blame arising from oil spills. We now discuss these lenses in turn.

\subsection{Sensegiving}

van Halderen et al. (2016) consider sengegiving as a tactic companies use to manage the impression of stakeholders to attenuate stakeholder pressures over corporate social and environmental responsibility. It is also perceived as a strategy companies facing increasing stakeholder pressures deploy in a sense of clarifying somewhat 'confused' narratives and asserting their preferred position (van Halderen et al., 2016). When companies have preferred perspectives of an event, they give sense to manage corporate identity and key resource providers (Levine Daniel and Eckerd, 2019; van Halderen et al., 2016) to make the key stakeholders perceive and interpret the event in those preferred ways (Søderberg, 2003). Against this backdrop, sensegiving involves "the process of attempting to influence the sensemaking and meaning construction of others toward a preferred redefinition of organizational reality" (Gioia and Chittipeddi, 1991, p. 442). Sonenshein (2010) also posits that sensegiving is when narrative is deployed to influence others. Thus, to give sense can be construed as "the symbolic constructions used to create meaning for others" (Gioia and Chittipeddi, 1991, p. 446). In this regard, sensegiving acts as a form of negotiation process 
whereby actors try to 'sell' or enact their vision or intended reality to others in the context of crisis or change.

Stakeholders' perceptions regarding an issue can be altered when sensegiving is enacted. According to Drori and Ellis (2011, p. 2), "the act of sensegiving involves selecting and applying rhetoric, conversational and narrative strategies that reflect an attempt ... to shape cognitive, cultural-symbolic and action." Corporate narratives can thus evoke cognitive and social biases in that sensegiving is an active process by which actors strategically frame narratives to influence the perceptions of others (Arvidsson and Johansson, 2019; Levine Daniel and Eckerd, 2019; Merkl-Davies et al., 2011). As sensegiving is deployed in strategic change or crisis situation (Gioia and Chittipeddi, 1991; Levine Daniel and Eckerd, 2019), we draw on it to focus the paper's examination of corporate narratives on oil spills which are serious environmental crisis oil MNCs face in Nigeria coupled with the ambiguity surrounding their causes, and their potential to induce negative inferences and consequences from corporate stakeholders (particularly investors).

Firms use corporate report to give sense to their relevant stakeholders to change the inferences they make about the organisation (Jain and Prakash, 2017). Hence, organisations deploy sensegiving as a signalling mode during strategic change or crisis event with the aim to disrupt the status quo and reframe the existing perceptions (Gioia and Chittipeddi, 1991). In our empirical setting, the case companies would rationally enlist sensegiving with the aim to disrupt the general view that the recurring oil spills in Nigeria are caused by corporate negligence and influence stakeholders' perceptions to align with corporate frame, particularly in maintaining shareholder-centric ideology. As Arvidsson and Johansson $(2019$, p. 86) argue, "sense-giving is provided in a cognitive frame, i.e. an interpretative scheme ... aimed to agree with the followers' interest, values and beliefs as well as organizational activities, goals and ideology." Companies thus mobilise sensegiving as a strategic narrative to change stakeholders' negative perceptions emanating from oil spills environmental crisis linked to corporate operations. As such, the crisis-ridden companies would use narratives to shape their stakeholders' perceptions on the crisis event and weaken other competing narratives from external stakeholders (Higgins and Walker, 2012). With sensegiving narratives acting as signals, companies can employ narratives in a blame game to change or influence the perceptions and understanding of their audience (Pupovac and Moerman, 2017). Given the fact that "sensegiving signals are, by their very nature, interpretive" (Levine Daniel and Eckerd, 2019, p. 218), we enlist blame avoidance defensive behaviours to explore corporate sensegiving in relation to the causes of oil spills in Nigeria.

\subsection{Defensive behaviours}

Investors (and generally other stakeholders) will adversely react towards a company accused of negative environmental behaviour by external media if the alternative narratives (by those media) are reasonably credible (Carberry et al., 2018). When companies are faced with events that trigger negative perceptions from stakeholders, they are under pressure to use persuasive narratives to manage their audience's perceptions (Beelitz and Merkl-Davies, 2012; Boiral, 2013; Botes and Samkin, 2013; Higgins and Walker, 2012; Diouf and Boiral, 2017). Corporate environmental narratives are potent strategic persuasive tools to influencing the perceptions of corporate stakeholders in a specific direction (Higgins and Walker, 2012). This is visible where companies have come under stakeholders' criticisms over a range of perceived social and environmental breaches, especially when such incidents are unabated. However, corporate stakeholders may perceive independent third-party narratives 
on the environmental breaches more credible and less self-interested than corporate selfreports (Du and Vieira, 2012). It thus becomes incumbent on the companies to give credibly appealing narratives to their audience by using multiple evidences to support their claims. The reasonableness and logicality of such narratives can weaken alternative narratives (Higgins and Walker, 2012). Negative corporate incidents naturally provoke negative public reactions, thereby putting the companies under pressure to mobilise defensive accounts as strategic tools to avoid blame and favourably alter stakeholders' perceptions. Given this context, the allegedly blameworthy companies are incentivised to give a sense that apparently absolves themselves of blame. As such, we find Ashforth and Lee's (1990) blame avoidance defensive behaviours, particularly after-the-fact blame avoidance lens, useful in understanding the corporate narratives on the causes of oil spills in Nigeria, thus giving sense to stakeholders that the companies are competent and non-negligent in upholding environmental integrity.

According to Ashforth and Lee (1990, p. 626), to manage the "impression of competence and worth often involves the avoidance of blame for actual or anticipated negative outcomes." In the context of oil spill incidents in the Niger Delta, the related corporate narratives are after-the-fact narratives in that they are couched after oil spill incidents to explain their causes. As such, three elements of blame avoidance concepts by (Ashforth and Lee, 1990) will help us understand the nuances of corporate persuasive narratives of the causes of oil spill incidents. These concepts are namely, scapegoating, justifying and misrepresenting (Ashforth and Lee, 1990). Scapegoating involves "the assignment of blame for a negative outcome to an external factor(s) which is not entirely (or not at all) blameworthy" (Ashforth and Lee, 1990, p. 628). The actor provides an account that the cause of the negative outcome is known and deserves to be blamed. For example, when oil spills are attributed to sabotage, it means they are caused by external parties and so those parties are to blame rather than the company whose operation is linked to the event. Scapegoating evokes protection of self-image in that the actor feels handicapped in the given circumstance with a view to escaping accountability.

Another concept of blame avoidance is misrepresenting. Misrepresenting occurs when an actor engages in manipulating, obfuscating, distorting or embellishing information to avoid blame. Such tendencies are sustained in an ambiguity situation where an outcome can originate from multiple sources. Because of the ambiguity surrounding the causes of negative incidents such as the oil spills linked to corporate activities, a corporate actor may be motivated to give them self-serving interpretations. Lastly, another blame avoidance concept is justifying. According to Ashforth and Lee (1990), justifying follows the narrative pattern to minimize one's responsibility for certain events linked to one's activities or downplay the severity and consequences of the events. By implication, the actor considers the criteria used by others to judge the circumstance as inappropriate. A strand of justifying relates to using an appeal to authority to legitimise claims (Bradford and Garrett, 1995; Eweje and $\mathrm{Wu}, 2010)$. In relation to oil spill incidents, this would mean from corporate perspective that those who linked the major cause of oil spills to corporate negligence have used wrong methodology to reach their conclusion. Justifying potentially thrives where the actual cause of oil spills is surrounded by ambiguity, which equally accords foothold to misrepresentation.

\section{$4 \quad$ Data and methods}

This paper is a case study that examines how oil MNCs in Nigeria adopt defensive persuasive narratives to give sense to stakeholders over the causes of oil spills. The paper 
draws primarily on the relevant narratives by the companies and stakeholders given the frequency of oil spills in Nigeria (Table 1)[1]. The study is a longitudinal case study covering a 10-year period between 2006 - 2015. A longitudinal case study is adopted because of the perennial nature of the oil spill incidents unlike the one-off Exxon Valdez and BP Gulf of Mexico incidents. The period covered coincided with when the National Oil Spill Detection and Response Agency [NOSDRA] Act was enacted in 2006 partly as a reactive law to public agitations over the menace of oil spills. Beyond the enactment of the NOSDRA Act, this period also coincided with increasing stakeholder criticisms of the MNCs over oil spills, including counter allegations between the MNCs and the Nigerian government over the masterminds of sabotage and oil thefts. We focused on the big-five oil MNCs (Chevron, Eni, ExxonMobil, Shell [operating as Shell Petroleum Development Company - SPDC] and Total) because of their visible operations and widespread oil spills in Nigeria. We analysed their corporate documents (Table 2) comprising annual sustainability/CSR reports between 2006-2015[2], relevant accessible reports published by their Nigerian operations, and other relevant information on their websites (Livonen, 2018).

\section{[Insert Table 1]}

\section{[Insert Table 2]}

Given the acute stakeholder criticisms trailing oil spill incidents in Nigeria, we considered the imperativeness of multiple perspectives by analysing a combination of corporate self-reports, independent external accounts and interviews. Twenty stakeholder interviews in English were conducted between January and March 2012, which included seven environmental and community development NGOs [NGO 1 - NGO 7], ten community members from Rivers and Beyelsa States in the Niger Delta [CommStake 1 -CommStake 10], and three oil/gas and environmental legal experts [LegExp 1 - LegExp 3]. The community members were chosen because their communities had experienced oil spills and were involved in community leadership. A cap at ten participants was considered appropriate as each additional interview was consistent with the previous - a point of saturation (Guest et al., 2006). Semi-structured interviews provide an opportunity for an in-depth understanding of a phenomenon (Moll et al., 2006) in a flexible manner that allows the participants to express themselves naturally (Parker, 2003), thereby generating data to compare corporate claims (Lauwo et al., 2016). Corporate employees would have been interviewed for further insight had management given access and support (Laine et al., 2017). Data from interviews and the other external sources was used to compare, contrast and/or critique the corporate narratives. The independent external accounts include news media publications and publications by NGOs. News media publications (including broadsheet papers and business news) on oil spills were obtained via Factiva and Google search covering the period of 20062015, resulting in the selection of 105 news items. We used 'oil spill in Nigeria' and 'oil spill in the Niger Delta' as key phrases to achieve the specific and desired results. Stakeholders narratives - news items, publications and interviews - were analysed as cross-references to the corporate narratives (Adams, 2004; Dey et al., 2011).

On the analysis of the causes of oil spills, we read the corporate reports to identify the narratives relating to Nigeria and closely read the relevant texts to identify the causes attributed to oil spill incidents. Similarly, we examined the interviews and external documentary narratives to decipher how the external stakeholders framed the causes of oil spills in Nigeria. We adopted an iterative approach of analysis between the data and the 
themes that emerged (Arora and Lodhia, 2017) and linked them back to the blame avoidance concepts reflecting the senses the companies gave in seeking to appeal to the sensibilities of stakeholders (Ashforth and Lee, 1990). Hence, we first identified the key empirical themes that emerged from the data in relation to the causes of oil spill incidents and then mapped them onto the blame avoidance concepts of scapegoating, misrepresenting, and justifying (Ashforth and Lee, 1990). We mapped each theme onto the blame avoidance concept it fitted best with by gauging how those themes and concepts reflected the sense the companies sought to give to their audience. The researchers individually carried out the thematic mappings, then compared notes, and discussed and resolved the arisen minor discrepancies (Arora and Lodhia, 2017; Laine et al., 2017). However, without prejudice to the mapping based on best fit, we are aware that these themes may not be mutually exclusive to the blame avoidance concepts they are assigned. For example, sabotage can be a form of misrepresentation, while the way the MNCs present corrosion narrative can be a form of scapegoating.

\section{$5 \quad$ Analysis of empirical evidence}

Oil spills, particularly their cause, occupy a prominent space in the public scrutiny of the activities of the oil MNCs operating in Nigeria (Denedo et al., 2018; Egbon et al., 2018; Pupovac and Moerman, 2017). This is partly due to the magnitude of the oil spills, the MNCs linked to them, and the ambiguity surrounding the spills compared to other pollution such as gas flaring and waste discharges. While the cause of gas flaring can be directly linked to the MNCs, oil spills "are much more difficult to resolve, as the issue is fraught with the politics of scams, sabotage, theft and genuine grievance (European Parliament, 2011, p. 18). Given the negative perceptions stakeholders can form on the companies implicated in the perennial oil spills (Amir et al., 2017; Dong et al., 2014; Heflin and Wallace, 2017), those companies are under pressure to give sense through persuasive narratives to alter the negative perceptions towards them (see Boiral, 2013; Botes and Samkin, 2013; Detzen and Hoffman, 2018; Pupovac and Moerman, 2017). The empirical findings are now presented as follows.

\subsection{Scapegoating: Sabotage as the cause of most oil spills}

Oil spills attributed to sabotage are deemed to be caused by third parties and so are outside corporate control. Sabotage is strikingly important for oil companies in Nigeria as any company implicated in oil spills risks huge compensation liability to victims if the latter can establish that sabotage caused the oil spills. Corporate narratives from different sources have cited sabotage as the major cause of oil spills in Nigeria, which have apparently made other stakeholders to use the sabotage narrative as a reference point in framing their (counterlarguments. Chevron's CSR reports for 2006 to 2015 did not mention oil spills in Nigeria. Moreover, Chevron Nigeria Limited[3] made no disclosures about oil spills in its 2010 and 2012 CSR reports, except in its 2010 CSR report [p. 22] where it mentioned that the company had outstanding environmental performance in relation to spill outside sabotage. It was not discernible from ExxonMobil's Corporate Citizenship Reports for 2006-2015 that most spills resulted from sabotage as it did not make country-specific oil spills disclosures attributable to its Nigeria's operation. However, in media reports, ExxonMobil attributed the cause of some oil spills it contained and cleaned up to sabotage [Platts Commodity News, 2012; Sahara Reporters, 2012]. But Eni, Shell and Total explicitly argued that most of the oil spills from their Niger Delta facilities resulted from sabotage. For example,

"In Nigeria there continue to be sabotages and thefts which in the last 4 years have 
resulted in ... an average of 300 incidents per year (284 in 2014)." [Eni 2014, pp. 5960; cf. Eni 2011, p. 42; 2015, p. 38].

"The great majority of oil spills in Nigeria are the result of sabotage or are caused when thieves drill into pipelines or damage wellhead equipment to steal oil ... such spills ... accounting for $98 \%$ of total Spdc spills volume" [Shell 2009, p. 22; cf. Shell 2010, p. 19, 30; Shell Nigeria 2011a, 2011b]

News media also reported corporate allegation of sabotage. For example, according to Associated Press (9 July 2012), Eni blamed sabotage for the spill that occurred on its Nembe-Obama Pipeline. While corporate narratives generally attributed the oil spills in the Niger Delta to sabotage, other stakeholders have countered the sabotage narratives as follows:

"There was an incident [spill] that happened in this community last year [2011], I ... took my bike and I got to the place.... Then few hours later the Agip people came. As soon as the Hilux [vehicle] just stopped, the man had not even come down, he said this one is sabotage" [CommStake 1]

"Shell looks to blame others based on investigation reports that, in some cases, amount to nothing more than dodgy dossiers ... Shell has made some improvements to its investigation reports since 2011, including the addition of images of oil spills on its corporate website. But serious flaws remain, including weaknesses in the underlying evidence used to attribute spills to sabotage" [Channels Television, 7 November 2013]

"In a statement signed by the Chairman Senate Committee on Environment Senator Bukola Saraki ... there have been media reports of two oil spills within the precincts of ExxonMobil Nigeria operations in Akwa Ibom state. He said there is a growing impression today that majority of the spills are the result of sabotage. However, with the recent spills happening deep offshore, it is becoming evident that there is more to this than meets the eye" [Legal Oil, 2012; see also Channels Television, 24 December 2012]

The above-mentioned doubt expressed by Senator Bukola Saraki about onshore and offshore oil spills is apparently shared by one of the interviewed legal experts who claimed that:

"The oil companies have never ever accepted spill is caused by them; they always say it is [caused by] sabotage, especially if it is onshore. They don't ever. But for offshore they can agree because they know that nobody could get there. But anything onshore, it is sabotage" [LegExp 3]

Furthermore, stakeholders considered oil companies' sabotage allegation as an excuse to avoid accountability and payment of compensation to victims of oil spills because of the legal incentives underpinning the claim. Various stakeholders have linked corporate allegation of sabotage with compensation avoidance as follows:

"When corporations talk of sabotage, they are hiding certain facts. One, they are unable to police their oil facilities and as a result they are blaming third parties. So the 
action of the third party cannot be made as the action of the main victim. In other words, if oil is spilled on a farm by a third party, what relationship has that to do with the victim? The victim is not the third party. You can see that it is a matter of convenience for the oil companies to claim sabotage in order to evade responsibility and accountability ... But they choose to hide under the claim of sabotage to evade payment of compensation and clean up" [NGO 2]

"From January to February [2012], we have already recorded about 8 to 9 pollution [oil spills] and none is sabotage. Although none is sabotage, none will be paid [attract compensation]" [CommStake 5]

Oil companies risk huge compensation payment for oil spills attributed to them if they are found guilty of causing such oil spills according to the following narrative:

"Shell Nigeria Exploration and Production Company, SNEPCO, was, yesterday, ordered by Nigerian Maritime Administration and Safety Agency, NIMASA, and the National Oil Spill Response and Emergency Agency, NOSREA, to pay a total of \$11.5 billion, about N1.84 trillion, as fines and compensation for the 2011 Bonga oil spill incident" (All Africa, 30 January 2014]

Hence, the stakeholders argue that the sabotage claim is a protective cover for the oil companies to evade paying compensation to victims of oil spills particularly because the Nigerian law disapproves compensation payment for sabotage-induced oil spills [Amnesty International, 2009, p. 17]. Shell also stresses this fact that:

"Where the investigation shows that the spill was within SPDC's control to prevent, SPDC negotiates compensation with the affected landowners. In 2010, SPDC paid more than $\$ 1.7$ million in compensation. Nigerian law does not require payment of compensation in cases of sabotage" [Shell Nigeria 2011c, p. 2]

While the Nigerian law exempts the oil companies from paying compensation to the victims of sabotage-induced oil spills, it confers additional advantage on the companies by placing the burden of proof of non-sabotage on the victims (Adewale, 1989). Even with proofs beyond reasonable doubt, stakeholders remain cynical that the MNCs will capitalise on the weak and slow legal system to frustrate justice and avoid paying compensation (Frynas, 2001; Milieudefensie, 2015; Omeje, 2006). The following narratives corroborate such stakeholders' cynicism.

"Some leaders of the communities had in 1983, dragged the oil company before a High Court... In a judgment it delivered on May 27, 1997, ... the High Court adjudged the matter in favour of the communities. Dissatisfied with the judgment, Shell Petroleum Development Company of Nigeria Limited took the matter before the Court of Appeal in Benin City. In a verdict it gave on May 22, 2000, the appellate court, affirmed the decision of the trial court and directed the company to immediately pay compensation to the four communities. Determined not to pay the communities, the oil company approached the Supreme Court, praying it to set aside the concurrent judgements of the two lower courts. Nevertheless, delivering judgment on the matter yesterday, a five-man panel of Justices of the apex court, led by Justice John Fabiyi, dismissed the appeal as grossly lacking in merit" [The Vanguard, 6 June 2015] 
"What Agip does sometimes is that when spill occurs, they will always call them sabotage. There was a case of a spill like that too in 2006, two spills occurred at the same time, they came with the JIV and they gave their report as equipment failure. The community people were there. Government representatives were there. Agip people were there ... They said it was equipment failure. But on their way going back, they agreed among themselves and changed it that it was sabotage. And no compensation was paid even till today [2012]" [CommStake 10]

\subsection{Misrepresenting: Corrosion/equipment failure causes only minimal oil spills}

Corrosion narrative is another corporate account on the source of oil spills in Nigeria, which is equally highly disputed by stakeholders like the sabotage narrative as it represents the flip side of sabotage. Corrosion is inversely related to sabotage because attributing most oil spills to sabotage means less oil spills are caused by corrosion. Inaccuracy associated with such corporate attribution, whether intentionally or unintentionally, risked misrepresentation of facts. Given corporate claims that most oil spill incidents emanate from sabotage, the companies are naturally claiming that corrosion contributes only minimally to the oil spills in Nigeria. By implication, the companies are alleging that alternative claims that attribute most oil spill incidents to corrosion are misrepresentations of fact. Some corporate corrosion narratives are:

"Although we had no pollution incidents to report in 2010, we experienced 20 between 2006 and 2009 on our only operated onshore project, OML 58. Fifteen were caused by acts of vandalism [sabotage] and five occurred as a result of technical incidents (corrosion or accidents)" [Total 2010, p. 57]

"The major oil spills are caused by acts of sabotage or terrorism. Further causes may be attributed to operating problems (collisions, seal failure etc.) and corrosion or breaks [Eni 2006, p. 54]

However, stakeholders allege that most oil spills emanate from corrosion rather than sabotage due to the aged oil pipelines, but this point is apparently suppressed in the corporate narratives. The companies are silent on their aged pipelines conveying high pressure crude oil in the region. Whereas the MNCs affirmed that corrosion minimally caused the oil spills, stakeholders argued that it caused most of the spills because of the over-aged pipelines. For example, an independent investigation done by a prominent Nigerian newspaper, The Nations, suggests that not less than $50 \%$ of oil spills are caused by corrosion due to the aged pipelines [Legal Oil, 2010]. Despite the stakeholders' claims about the aged pipelines [see Amnesty International, 2009, 2013; Christian Aid, 2004; Steiner, 2010], the companies are silent about them when they mention equipment failure or corrosion. The following narratives also indict the companies of cover-ups on their ageing pipelines in the Niger Delta.

"By 1994 Shell privately admitted that SPDC had ageing and polluting infrastructure that was "unacceptable." One document noted, "Key aspects of the past environmental practices of the SPDC operation also fall short of current standards and leave a significant legacy of problems to be resolved." [Stockman et al., 2009, p. 17]

"Shell failed to act on its own internal advice to replace a 30-year-old pipeline years before it wreaked havoc on the Niger Delta by rupturing and spilling thousands of 
barrels of oil into the area, according to court documents. The two giant spills, in 2008, affected about 35 square miles of southern Nigeria, including sensitive mangroves, and ruined the livelihoods of up to 15,000 villagers in Bodo in Ogoniland, who are suing the company in London in a case due to start in May[4]." [The Independent, 13 November 2014]

Although all the MNCs failed to mention the life cycle of their pipelines, the massive annual pipeline replacement programmes of the oil companies appear to allude to stakeholders' claims about the companies' ageing pipelines.

"Stopping spills under its direct control is a key priority for SPDC. In 2011, work to maintain and replace pipelines and other infrastructure continued. In the past three years, SPDC has replaced about $400 \mathrm{~km}$ of pipeline, and work continues to replace further pipelines." [Shell, 2011, p. 19]

"A key priority for SPDC is to achieve its goal of no operational spills. In 2013, it continued work to maintain and replace pipelines and other infrastructure and, in the past three years, SPDC has replaced around $770 \mathrm{~km}$ of pipeline." [Shell 2013, p. 23]

"To reduce the number of operational spills, the SPDC JV continues to work to maintain and replace sections of pipeline and other infrastructure, installing $132 \mathrm{~km}$ of new pipeline during the year." [Shell 2014, p. 36]

While pipeline replacement programme is commendable as it can eliminate corrosioninduced oil spills, the narrative indirectly alludes to ageing pipelines with implications for corrosion and oil spills. Such a subtle approach to reporting is a strategic use of narrative to shape cognitive bias and promote a particular worldview (Drori and Ellis, 2011) to reflect what appeals to the audience (Rouleau, 2005).

Interviewees also expressed their concerns over the integrity of oil pipelines in the Niger Delta. As such, they have argued that most of the oil spills were caused by ageing pipelines, which are susceptible to corrosion and leakages according to the following narratives.

"You see, under pipeline integrity, a pipeline ought not to be more than 25 or 30 years old, but most of our pipelines are over 50 years old. So what do you think about that? Are they not breaking up by themselves? They are breaking up by themselves because the pressure inside is much. They cannot say spills are caused by sabotage, but what they say is a cooked-up excuse" [NGO 3]

"You know the pipeline that conveys oil to the Trans-Niger [terminal] is steadily flowing. And look at the age of the pipeline ... it is over-aged and when it spills it just spills like that" [CommStake 3]

"All oil spills are not sabotage. They also arise as a result of negligence of these oil companies because some of these pipes have been on the ground for a period of 50 , 60 years. They are now corrosive." [LegExp 3]

\subsection{Justifying: Joint Investigation Visit (JIV) as a collaborative decision}

In seeking to make the allegation of sabotage persuasive to corporate audience, the 
companies mobilise the JIV narrative to justify their sabotage claims. Justifying aims at demonstrating that the companies relied on credible evidence to reach the sabotage conclusion, thereby subordinating stakeholders' claims as unsupported by evidence. JIV serves that purpose. JIV supposedly provides multi-stakeholders evidence-based findings and decisions on the causes of oil spills. The JIV narrative thus assumes that the alleged causes of oil spills are determined through the JIV as an independent and objective mechanism as presented below:

"When an oil spill occurs, a joint investigation team visits the site as quickly as possible to establish the cause and volume of the spill. The team is led by SPDC, and includes representatives of the regulatory bodies and the Ministry of Environment. The police, state government officials and impacted communities are also invited to attend the visit" [Shell Nigeria 2011d, pp. 1-2; cf. Shell 2013, p. 23]

Eni also considered the JIV as a mechanism for working with local authorities and communities' representative to promote joint investigation due to the allegedly alarming rate of sabotage [Eni 2006, p. 96] and to determine the causes of oil spills [Eni 2009, p. 75]. The other MNCs did not talk about JIV exercise. By drawing public attention to the JIV, the companies are apparently brandishing a showmanship of stakeholder collaborative decisions. It portrays an image of transparency and collective actions involving corporate-stakeholder joint determination of the causes of the oil spills. As such, the JIV narrative seeks to justify the credibility of corporate claims that most of the oil spills are caused by sabotage and less by corrosion or equipment failures. In fact, regulation prescribes a JIV whenever oil spills occur and provides for a joint investigation within 24 hours when oil spills occur [EGASPIN, 2002]. Whereas the MNCs attach credibility to the JIV with its outcomes, stakeholders discredit the JIV exercise because of corporate control over it as the regulators overseeing the exercise depend on the companies for JIV logistics (see Babatunde, 2020; UNEP, 2011). Stakeholders not only perceive the action as inappropriate for independence [UNEP, 2011], but also believe it compromises the credibility of the investigation as the process risks corporate control [Amnesty International, 2009; Ecumenical Council for Corporate Responsibility [ECCR], 2010]. Interviewees also share similar concern about the credibility of the JIV exercise:

What Agip does sometimes is that when spill occurs, they will always call them sabotage. There was a case of a spill ... in 2006, two spills occurred at the same time, they came with the JIV and they gave their report as equipment failure. The community people, Government and Agip representatives were there. They said it was equipment failure, but they later claimed it was sabotage. And no compensation was paid even till today." [CommStake 5]

"What they do is that they will just bring a plain paper and ask you to sign and they
will tell you that they can't fill their report in the field and that when they get to the
office they will collate [complete] the report. ... Some [community] boys who are not
grounded [ignorant], when they [MNCs] find [give] them a little thing [incentive] they
will sign it." [CommStake 3]

The view of corporations seeking to manipulate the JIV outcome is also shared by some other stakeholders who accused the MNCs of hijacking the JIV process to manipulate its outcomes [e.g., NGO 3; Amnesty International, 2013]. For example, the narrative below alleges Shell's attempt to comprise a JIV report: 


\begin{abstract}
"Amnesty International also claimed to have secretly filmed video of an investigation showing how officials from Shell and the regulator tried to subvert the evidence by persuading community members on the investigation team not to attribute the cause to equipment failure." [Channels Television, 2013]
\end{abstract}

Similarly, a State Commissioner in the Niger Delta have also called to question the credibility of the JIV process in the following narrative:

"Mr. Wills, the Bayelsa Commissioner for Environment, noted that the state government had resolved to overhaul the entire spills and pollution response process. "We have noted that the joint investigation procedure had not achieved the desired result and we are resolved to follow up the entire process in detail. Our technical staff have been so directed to be fully involved," said the commissioner" [Sahara Reporters, 15 March 2015]

However, corporate view on the credibility of the JIV process and outcomes is further buttressed by the alleged inclusion of independent NGO group in all JIV exercises. For example:

"SPDC continued to work with communities and civil society to build greater trust in spill response and clean-up processes. Representatives of the principal NGO coalition in the Niger Delta, called the National Coalition on Gas Flaring and Oil Spills in the Niger Delta (NACGOND), are invited to join all Joint Investigation Visits. These visits assess the cause and extent of oil spills" [Shell 2014, p. 37].

Whereas the above claim potentially increases the JIV's credibility, it is unclear whether the NGO coalition indeed attend all the exercises upon invitations. Given that Shell's 2014 invitation claim preceded the representation made in 2015 by the Bayelsa Commissioner for Environment, it could be inferred that the JIV credibility concerns were still unresolved.

\title{
6 Discussion of findings
}

This paper was motivated to explore how the big-five MNCs in the Nigerian oil industry deployed strategic narratives on the causes of oil spills as signals to induce the favourable perceptions of their audience, particularly, their investors. The empirical analysis has demonstrated how corporate narratives have been strategically framed around blame avoidance to give sense to the corporate audience, or influence their perceptions, particularly with evidence that appears transparent and persuasive. Since the investors of the case companies are detached from the companies' operations, the companies perceive to use corporate narratives as strategic instruments to meet their stakeholders' information needs with respect to crisis incidents - oil spills in this context (Pupovac and Moerman, 2017). The companies have used narratives as signals to give sense to and create meaning for their audience, thereby supporting the view of sensegiving as "the symbolic constructions used to create meaning for others" (Gioia and Chittipeddi, 1991, p. 446) and a signalling instrument "intended to supplant or re-frame existing conceptions" (Gioia and Chittipeddi, 1991, p. 439). Our findings showed that the case companies mobilised blamed avoidance narratives in reframing the causes of oil spill incidents in Nigeria. While these framings (scapegoating, misrepresenting and justifying) are aimed at influencing the perceptions of the audience, the 
extent they transparently portray the crisis reality and the discharge of the related accountability remains doubtful.

Our empirical analysis showed that the MNCs attributed the cause of most oil spills in Nigeria to sabotage (the actions of third parties). This represents a scapegoating phenomenon in that it shifts blame from the companies to third parties (Ashforth and Lee, 1990). However, this view has been criticised by other stakeholders who have considered the corporate claims as exaggerations to evade payment of compensation to the victims of oil spills. As such, the stakeholders believed that most of the oil spills were caused by corrosion based on the evidence of over-aged pipelines, while the companies alleged that only a minimal amount of oil spills emanated from corrosion or equipment failures. Ageing pipelines have been linked to internal and external corrosion and numerous oil spills in Nigeria (see Lilly et al., 2007). Although the companies did not refute the aged pipeline allegation, they maintained silence on it. But Shell's annual replacement of significant portions of its pipelines indirectly confirmed stakeholders' allegation of critical ageing pipelines and hence corrosion.

Thus, corrosion narratives are apparently underpinned by the notion of misrepresenting, obfuscating or suppressing facts. Our empirical analysis considered misrepresenting in the context of oil spills as deriving broadly from the MNCs potentially misclassifying corrosion as an insignificant cause of oil spills to favourably influence stakeholders' perceptions. Both the MNCs and stakeholders agreed that sabotage have caused oil spills in Nigeria, but they disagreed on the ground of sabotage-corrosion disproportionate classification. For example, the revelations from Amnesty International's commissioned scientific investigations into the causes of several spills in the Niger Delta and Amnesty International's conversations with the oil companies suggest a high degree of misclassification of corrosion-induced oil spills as sabotage-induced (see Amnesty International, 2013). Such a disproportionate classification that most oil spills are caused by sabotage absolves the oil companies of potential liability to oil spills' victims (Adewale, 1989), which is further enhanced by the likelihood that the Nigerian courts would endorse the MNCs' allegations (Frynas, 1999).

In addition to mobilising scapegoating (sabotage) and misrepresenting (corrosion) blame avoidance narratives to account for the causes of oil spills in Nigeria, the companies adopted justifying (JIV) blame avoidance narrative to reinforce their sabotage-corrosion claims. Justifying potentially thrives where the actual cause of the oil spills is surrounded by ambiguity. As Ashforth and Lee (1990) argue, justifying follows the narrative pattern to minimize one's responsibility for certain events linked to one's activities or downplay the severity and consequences of the events. By implication, the actor considers the criteria others used to judge the circumstance as inappropriate and draws on appeal to authority to legitimise claims (Bradford and Garrett, 1995; Eweje and Wu, 2010). This suggests that those who linked the major cause of the oil spill incidents to corporate negligence (corrosion) rather than sabotage have used wrong methodology to reach their conclusion. So, the companies justified their sabotage-corrosion claims using the JIV narrative to demonstrate that the conclusion that oil spills emanated from sabotage or corrosion was collaboratively determined by the companies and other stakeholders. Nonetheless, the images of credibility and collective decision on the causes of the oil spills created by the corporate narratives may not represent the reality and as such may bias transparency (Boiral, 2013).

Whereas the MNCs created the impression that they objectively determined the causes of oil spills through JIV architecture, other empirical evidence portrayed the JIV process as lacking in credibility. In framing sabotage as a persuasive narrative, the companies 
have alluded to the JIV as a multi-stakeholder exercise for assessing the causes and severity of oil spills in Nigeria, albeit stakeholders' concern about its corporate capture. Besides serving as a mechanism for determining the causes of oil spills, the JIV serves as an instrument the companies use to determine whether they are liable to compensate the victims of oil spills. Sabotage and corrosion have implications for corporate liability and compensation payments to victims of oil spills as spills attributed to sabotage attract no compensation payment, while the law also places the burden of proof on the victims of the oil spills. With the law putting the burden of proof on the victims of oil spills to prove that the spills for which they are seeking compensation did not arise from sabotage (Adewale, 1989) coupled with the involving technicalities and litigation process (Frynas, 1999; Milieudefensie, 2015), stakeholders believed that the oil companies are thus incentivised to use sabotage as a matter of convenience to avoid compensation liabilities. This finding shows the disproportionate convenience for the companies to allege sabotage than corrosion as the major cause of oil spills by the symbolic credibility they attach to the JIV exercise, while the law that puts the burden of proof on the oil spills' victims to prove that the spills were not caused by sabotage further complicated the issue. Despite the risk of misclassifying the causes of oil spills, the Nigerian law exempts the companies from paying compensation to the victims of alleged sabotage-induced oil spills. This syncs with the commentaries that Nigeria lacks the regulatory power to compel oil MNCs to address environmental problems arising from their operations (Nwoke, 2016).

This macro-contextual factor further complicated and obscured the transparent discharge of accountability because of the positive incentive it created for the companies to allege that most spills were caused by sabotage. Hence, this raises the need for future investigation into how socio-political contextual dynamics complicate corporate accountability. From the empirical data, the case companies strategically framed blame avoidance narratives that apparently appeal to their investing audience by drawing on the available loopholes within the complex social contexts from which those narratives derived (Botes and Samkin, 2013; Pupovac and Moerman, 2017). Consequently, the socio-political dynamics and complexities within a social context can make companies to continue their operations with impunity amid enormous perennial pollution generated by their operations. In contrast, one-off oil spill incidents such as the Exxon Valdez and BP Gulf of Mexico oil spills in the US instigated public outcries that engendered corporate apologies and reassuring commitments to avert future reoccurrences (see Botes and Samkin, 2013; Wehmeier and Schultz, 2011).

\section{Conclusion}

This case study on corporate accountability with respect to oil spill incidents in Nigeria has examined how the oil MNCs adopted defensive behaviours (blame avoidance narratives) to give sense to their stakeholders over the causes of oil spills. The empirical analysis has shown how the corporations gave sense to their audience by invoking scapegoating blame avoidance narrative in attributing the cause of most oil spills in Nigeria to the actions of outsiders (sabotage), despite potentially misclassifying the sabotage-corrosion dichotomy. The corporations reinforced their stance through justifying narrative, suggesting that the causes of the oil spills were jointly determined by multi-stakeholders, thus portraying corporate account as transparent, credible and objective. While stakeholders believed that sabotage also caused oil spills in Nigeria, they argued that most of the oil spills emanated from corrosion due to the ageing pipelines which are highly susceptible to corrosion. They further 
argued that the MNCs have been attributing most oil spills to sabotage to avoid paying compensation to oil spill victims because the law exempts the companies from paying them compensation for spills allegedly caused by sabotage. With the law permitting payment of compensation to only the victims of non-sabotage-induced oil spills alongside placing the burden of proof on those victims, the MNCs are legally incentivised to attribute most oil spills to sabotage. Serious accountability tension is thus created, not only because the law tasks the oil spill victims (usually poor community members) to prove the cause of the pollution but also even when it is proven beyond reasonable doubt the companies still uses their influence to frustrate justice. The policy implication of this is that accountability would be best served when the MNCs are tasked both with the burden of proof and a responsibility to demonstrate their transparency in preventing oil spills, including those caused by sabotage.

Our study has provided some nuanced insights into the accountability practices of environmentally sensitive industries in developing economies - specifically Nigeria, where the environmental pollution from oil operations is both perennial and pervasive. It contributed to the wider literature of corporate accountability by providing insights into how organisations operating in a sensitive and complex social context engage in sensegiving by deploying blame avoidance narratives to influence stakeholders' perceptions favourably towards themselves despite the persistent environmental pollution linked to their operations. The paper also complemented studies on corporate impression management as sengegiving is construed as a tactic of impression management (van Halderen et al., 2016). Many prior studies have examined a single environmental incident and how the implicated companies deployed narratives to alter the perceptions of their audience (Beelitz and Merkl-Davies; Botes and Samkin, 2013; Ruffing, 2007; Summerhays and de Villiers, 2012). Pupovac and Moerman (2017) equally demonstrated how Shell deployed rhetorical narratives as powerful instruments to persuade its audience about its responsiveness and transparency with respect to the oil spill incidents linked to its operation in Nigeria. Our paper provided further insight on the role of narratives within the same messy context by exploring how the big-five oil MNCs (Chevron, ExxonMobil, Eni, Shell and Total) strategically used blame avoidance defensive narratives to alter stakeholders' perceptions on the causes of oil spills in Nigeria. It is thus observable that accounts-giving is not only about satisfying accountability demands, but also a sensegiving mode aimed at reframing or redefining existing perceptions.

By drawing on the SEA reports of the case companies, the paper found the corporate narratives helpful in gaining further insight into how corporations strategically frame persuasive narratives when faced with legitimacy-threatening situations so they not only avoid negative reactions from their investors but also continue to enjoy their support. For example, despite the perennial oil spills linked to the MNCs' operations in Nigeria and the public outcries, the companies have yet to receive damning consequences from their investing community over the pollution (Bovens, 2007). As the companies used narratives to give sense to their perceived salient stakeholders on the reality of oil spill incidents in Nigeria (Pupovac and Moerman, 2017), those stakeholders appear to consider the corporate narratives persuasive and credible as they continue to support the companies investment wise (Carberry et al., 2018). It implies that corporate defensive blame avoidance narratives are effective sensegiving signals as they appeared to have favourably influenced the investing community's perceptions towards the companies despite the persistent oil-induced corporate environmental pollution.

In addition, the study has provided implicit insight into how powerful audience perceive the credibility of corporate narratives over other competing perspectives (Carberry 
et al., 2018) based on how companies with legitimacy-threatening environmental crisis strategically frame narratives to induce the continuous support of the audience. Given the complexity and opaqueness of the Nigerian oil industry (Egbon et al., 2018), our findings imply that the social complexities, socio-political dynamics, and regulatory laxity in an empirical context/country could make corporate narratives on poor environmental outcomes appear persuasive and coherent. As such, corporate environmental narratives and actual corporate environmental practices will almost always remain disproportionate (Cho et al., 2015, 2018; Rhee and Lee, 2003). Future studies may look at how the macro institutional, legal and political environments interact to influence both the corporate environmental practices of companies and the related accountability.

\section{Endnote}

1. There is no clear-cut data on which company faces higher spills than the others. However, Shell has been more on the spotlight than the others. The figure of oil spills reported is likely understated as minor spills may have been ignored (European Parliament, 2011). Segregating spills by each company is constrained by data access.

2. A review of the MNCs' sustainability/CSR reports in 2016 to 2018 does not reveal any materially dissimilar narratives.

3. Chevron's subsidiary operating in Nigeria.

4. In January 2015 , Shell quickly settled out of court by agreeing to pay the victims $f 55 \mathrm{~m}$ (Leigh Day, 2015). 


\section{References}

Adams, C.A. (2004), "The ethical, social and environmental reporting-performance portrayal Gap", Accounting, Auditing \& Accountability Journal, Vol. 17 No. 5, pp. 731-757.

Adewale, O. (1989), "Oil spill compensation claims in Nigeria: principles, guidelines and criteria", Journal of African Law, Vol. 33 No. 1, pp. 91-104.

All Africa (2014, January 30), "Nigeria - Bonga oil spill - FG fines Shell \$11.5 billion”, Available at: http://royaldutchshellplc.com/2014/01/30/nigeria-bonga-oil-spill-fg-fines-shell11-5-billion/ (Accessed 18 August 2018)

Amir, S., Sabet, H., Cam, M. and Heaney, R. (2017), "Share market reaction to the BP oil spill and the US government moratorium on exploration", Australian Journal of Management, Vol. 37 No. 1, pp. 61-76.

Amnesty International (2009), Petroleum, pollution and poverty in the Niger Delta, Amnesty International, London.

Amnesty International (2013), Bad information: oil spill investigations in the Niger Delta, Amnesty International, London

Arora, M. P. and Lodhia, S. (2017), "The BP Gulf of Mexico oil spill: Exploring the link between social and environmental disclosures and reputation risk management", Journal of Cleaner Production, Vol. 140 No. 3, pp. 1287-1297.

Arvidsson, S. and Johansson, J. (2019), "Sense-making and sense-giving: reaching through the smokescreen of sustainability disclosure in the stock market", In Arvidsson, S. (ed.), Challenges in managing sustainable business: reporting, taxation, ethics and governance, Palgrave Macmillan, Cham, Switzerland, pp. 77-109

Ashforth, B.E. and Lee, R.T. (1990), "Defensive behavior in organizations: a preliminary model", Human Relations, Vol. 43 No. 7, pp. 621-648.

Associated Press (2012, July 9), "Italian oil major Eni blames 'sabotage' for oil spill in Nigeria's Southern Delta" Available at: http://global.factiva.com.ezproxy.standrews.ac.uk/aa/?ref=APRS000020120709e879001pp\&pp=1\&fcpil=en\&napc=S\&sa from $=$ (Accessed 23 December 2013).

Babatunde, A.O. (2020), "Oil pollution and water conflicts in the riverine communities in Nigeria's Niger Delta region: challenges for and elements of problem-solving strategies", Journal of Contemporary African Studies, pp. 1-20

Bebbington, J. Larrinaga, C. and Moneva, J.M. (2008), "Corporate social reporting and reputation risk management", Accounting, Auditing \& Accountability Journal, Vol. 21 No. 3, pp. 337-361.

Beelitz, A. and Merkl-Davies, D. (2012), "Using discourse to restore organisational Legitimacy: 'CEO-speak' after an incident in a German Nuclear Power Plant", Journal of Business Ethics, Vol. 108 No. 1, pp. 101-120.

Belal, A.R., Cooper, S.M. and Roberts, R.W. (2013), "Vulnerable and exploitable: The need for organisational accountability and transparency in emerging and less developed economies", Accounting Forum, Vol. 37 No. 2, pp. 81-91.

Boin, A., Hart, P. and McConnell, A. (2009), "Crisis exploitation: political and policy impacts of framing contests", Journal of European Public Policy, Vol. 16 No. 1, pp. 81-106.

Boiral, O. (2013), "Sustainability reports as simulacra? A counter-account of A and A+ GRI reports", Accounting, Auditing \& Accountability Journal, Vol. 26 No. 7, pp. 1036-1071

Botes, V.L. and Samkin, G. (2013), "BP's use of posture to respond to the Deepwater Horizons crisis", Journal of Economic and Financial Sciences, Vol. 6 No. 2, pp. 359-382.

Bovens, M. (2007), "Analysing and assessing accountability: a conceptual framework", 
European Law Journal, Vol. 13 No. 4, pp. 447-468.

Bradford, J. L. and Garrett, D. E. (1995), "The effectiveness of corporate communicative responses to accusations of unethical behaviour", Journal of Business Ethics, Vol. 14 No. 11, pp. 875-892.

Buccina, S., Chene, D. and Gramlich, J. (2013), "Accounting for the environmental impacts of Texaco's operations in Ecuador: Chevron's contingent environmental liability disclosures", Accounting Forum, Vol. 37 No. 2, pp. 110-123.

Channels Television (2012, December 24), “Oil Spill: Senate Demands Answers From NOSDRA, Ministry and Mobil", http://www.channelstv.com/home/2012/12/24/oilspill-senate-demands-answers-from-nosdra-ministry-and-exxon-mobil/ (Accessed 3 February 2014).

Channels Television (2013, November 7), "Groups expose false claims by Shell on oil spills", Available at: http://www.channelstv.com/home/2013/11/07/groups-expose-falseclaims-by-shell-on-oil-spills/ (Accessed 7 November 2013).

Cho, C.H., Laine, M., Roberts, R.W. and Rodrigue, M. (2015), "Organized hypocrisy, organizational facades and sustainability reporting", Accounting, Organizations \& Society, Vol. 40, pp. 78-94.

Cho, C.H., Laine, M., Roberts, R.W. and Rodrigue, M. (2018), "The frontstage and backstage of corporate sustainability reporting: evidence from the Arctic National Wildlife Refuge Bill", Journal of Business Ethics, Vol. 152, pp. 865-886

Christian Aid (2004), Behind the mast: the real face of corporate social responsibility, Organisation, London.

Deegan, C. Rankin, M. and Voght, P. (2000), "Firms' disclosure reactions to major social incidents: Australian evidence", Accounting Forum, Vol. 24 No. 1, pp. 101-130.

Denedo, M., Thomson, I. and Yonekura, A. (2017), "International advocacy NGOs, counter accounting, accountability and engagement", Accounting, Auditing \& Accountability Journal, Vol. 30 No. 6, pp. 1309-1343

Denedo, M., Thomson, I. and Yonekura, A. (2018), "Accountability, maps and intergenerational equity: evaluating the Nigerian oil spill monitor", Public Money \& Management, Vol. 38 No. 5, pp. 355-364.

Denedo, M., Thomson, I. and Yonekura, A. (2019), "Ecological damage, human rights and oil: local advocacy NGOs dialogic action and alternative accounting practices", Accounting Forum, Vol. 43 No. 1, pp. 85-112.

Detzen, D. and Hoffmann, S. (2018), "Stigma management and justifications of the self in denazification accounts", Accounting, Auditing and Accountability Journal, Vol. 31 No. 1, pp. 141-165.

Dey, C. (2003), "Corporate 'silent' and 'shadow' social accounting" Social and Environmental Accountability Journal, Vol. 23 No. 2, pp. 6-9.

Dey, C., Russell, S. and Thomson, I. (2011), "Exploring the potential of shadow accounts in problematising institutional conduct", In Osbourne, S.P. and Ball, A. (Eds.), Social accounting and public management: accountability for the public good, Routledge, New York, pp. 64-75.

Diouf, D. and Boiral, O. (2017), "The quality of sustainability reports and impression management: a stakeholder perspective", Accounting, Auditing \& Accountability Journal, Vol. 30 No. 3, pp. 643-667.

Dong, S., Burritt, R. and Qian, W. (2014), "Salient stakeholders in corporate social 
responsibility reporting by Chinese mining and minerals companies", Journal of Cleaner Production, Vol. 84, pp. 59-69

DPR (2016), "Oil \& Gas Annual Report”, Available at: https://dpr.gov.ng/wp-content/uploads/2018/04/2016-Oil-Gas-Industry-AnnualReport.pdf (Accessed 8 August 2018)

Drori, I. and Ellis, S. (2011), "Conflict and power games in a multinational corporation: Sensegiving as a strategy of preservation", European Management Review, Vol. 8, pp. 1-16.

Du, S. and Vieira, E.T. (2012), "Striving for legitimacy through corporate social responsibility: insights from oil companies", Journal of Business Ethics, Vol. 110 No. 4, pp. 413-427.

ECCR (2010, February), Shell in the Niger Delta: a framework for change, Ecumenical Council for Corporate Responsibility, Oxford.

EGASPIN (2002), Environmental Guidelines and Standards for the Petroleum Industry in Nigeria, Revised ed. Department of Petroleum Resources, Lagos, Nigeria

Egbon, O., Idemudia, U. and Amaeshi, K. (2018), "Shell Nigeria's Global Memorandum of Understanding and corporate-community accountability relations: a critical appraisal", Accounting, Auditing \& Accountability Journal, Vol. 31 No. 1, pp. 51-74.

European Parliament (2011), The Effects of Oil Companies' Activities on the Environment, Health and Development in Sub-Sahara Africa, European Parliament, Brussels.

Eweje, G. and Wu, M. (2010), "Corporate response to an ethical incident: the case of an energy company in New Zealand", Business Ethics: A European Review, Vol. 19 No. 4, pp. 379-392.

Frynas, J.G. (1999), "Legal change in Africa: evidence from oil-related litigation in Nigeria. Journal of African Law, Vol. 43 No. 2, pp. 121-150.

Frynas, J.G. (2001), "Problems of access to courts in Nigeria: results of a survey of legal Practitioners", Social \& Legal Studies, Vol. 10 No. 3, pp. 397-419.

Gilstrap, C. A., Gilstrap, C. M., Holderby, K. N. and Valera, K. M. (2016), "Sensegiving, leadership, and nonprofit crises: how nonprofit leaders make and give sense to organizational crisis" VOLUNTAS: International Journal of Voluntary and Nonprofit Organizations, Vol. 27 No. 6, pp. 2787-2806.

Gioia, D.A. and Chittipeddi, K. (1991), "Sensemaking and sensegiving in strategic change Initiation", Strategic Management Journal, Vol. 12 No. 6, pp. 433-448.

Gray, R. (2000), "Current developments and trends in social and environmental auditing, reporting and attestation: a review and comment", International Journal of Auditing, Vol. 4 No. 3, pp. 247-268.

Guest, G., Bunce, A. and Johnson, L. (2006), "How many interviews are enough? An experiment with saturation and variability", Field Methods, Vol. 18 No. 1, pp. 59-82.

Heflin, F. and Wallace, D. (2017), "The BP oil spill: shareholder wealth effects and environmental disclosures, Journal of Business Finance and Accounting, Vol. 44 No. 3 \& 4, pp. 337-374.

Higgins, C. and Walker, R. (2012), "Ethos, logos, pathos: strategies of persuasion in social/environmental reports", Accounting Forum, Vol. 36, pp. 194-206.

Horbach, S.P.J.M., Breit, E. and Mamelund, S. (2019), "Organisational responses to alleged scientific misconduct: sensemaking, sensegiving, and sensehiding", Science and Public Policy, Vol. 46 No. 3, pp. 415-429.

Jain, S.S. and Prakash, A. (2017), "Signalling stewardship: the role of ownership identity in 
shaping social responsibility communication in India", The Journal of Corporate Citizenship Issue, Vol. 66, pp. 46-80.

Laine, M., Järvinen, J.T., Hyvönen, T. and Kantola, H. (2017), “Ambiguity of financial environmental information: a case study of a Finnish energy company", Accounting, Auditing \& Accountability Journal, Vol. 30 No. 3, pp. 593-619

Laine, M. and Vinnari, E. (2017), "The transformative potential of counter accounts: a case study of animal rights activism", Accounting, Auditing \& Accountability Journal, Vol. 30 No. 7, pp. 1481-1510

Lauwo, S.G., Otusanya, O.J. and Bakre, O. (2016), "Corporate social responsibility reporting in the mining sector of Tanzania: (lack of) government regulatory controls and NGO activism", Accounting, Auditing \& Accountability Journal, Vol. 29 No. 6, pp. 1038-1074

Leadership (2013, July 27), "Oil Majors responsible for crude oil theft", Available at: http://sardaunamagazine.com/index.php/sports-news/item/2142-oil-majorsresponsible-for-crude-oil-theft-kuku (Accessed 10 August 2013).

Legal Oil (2010, August 28), "Illegal bunkering: communities in the throes of devastation", Available http://www.legaloil.com/Newsltem.asp?DocumentIDX=1283626956\&Category=new s (Accessed 10 February 2014).

Legal Oil (2012, December 24), "Oil spill: Senate demands answers from NOSDRA, Ministry and Exxon Mobil", Available at: http://www.legaloil.com/Newsltem.asp?DocumentIDX=1356794146\&Category=new s (Accessed 3 February 2014).

Leigh Day (2015, January 7), "Shell agrees $f 55 m$ compensation deal for Niger Delta community", Available at: https://www.leighday.co.uk/News/2015/January2015/Shell-agrees-55m-compensation-deal-for-Nigeria-Del (Accessed 24 April 2018).

Levine Daniel, J. and Eckerd, A. (2019), “Organizational sensegiving: indicators and nonprofit Signalling", Nonprofit Management and Leadership, Vol. 30, pp. 213-231.

Lilly, M.T., IheKwoaba, S.C, Ogaji, S.O.T. and Probert, S.D. (2007), "Prolonging the lives of buried crude-oil and natural-gas pipelines by cathodic protection", Applied Energy, Vol. 84 No. 9, pp. 958-970.

Livonen, K. (2018), "Defensive responses to strategic sustainability paradoxes: have your coke and drink it too!", Journal of Business Ethics, Vol. 148 No. 2, pp. 309-327.

Merkl-Davies, D.M. and Brennan, N.M. (2011), "A conceptual framework of impression management: new insights from psychology, sociology and critical perspectives", Accounting and Business Research, Vol. 41 No. 5, pp. 415-437.

Moerman, L. and van der Laan, S. (2015), "Exploring shadow accountability: the case of James Hardie and Asbestos", Social Environmental Accountability Journal, Vol. 35 No. 1, pp. 32-48.

Nwagbara, U. and Belal, A. (2019), "Persuasive language of responsible organisation? A critical discourse analysis of corporate social responsibility (CSR) reports of Nigerian oil companies", Accounting, Auditing \& Accountability Journal, Vol. 32 No. 8, pp. 23952420.

Nwoke, U. (2016), "Two complimentary duties under corporate social responsibility: multinationals and the moral minimum in Nigeria's Delta region", International Journal of Law and Management, Vol. 58, No. 1, pp. 2-25.

Omeje, K. (2006), "The rentier state: oil-related legislation and conflict in the Niger Delta, Nigeria", Conflict, Security \& Development, Vol. 6 No. 2, pp. 211-230. 
Parker, L.D. (2008), "Interpreting interpretive accounting research", Critical Perspectives on Accounting, Vol. 19 No. 6, pp. 909-914.

Platts Commodity News (2012, August 20), "ExxonMobil says cleaning up oil spill in Nigeria, source still unknown", Available at: http://global.factiva.com.ezproxy.standrews.ac.uk/aa/?ref=PLATT00020120820e88k0010a\&pp=1\&fcpil=en\&napc=S\&sa_ from $=$ (Accessed 23 December 2013)

Ploeger, N.A. and Bisel, R.S. (2013), "The role of identification in giving sense to unethical organizational behavior: defending the organization", Management Communication Quarterly, Vol. 27 No. 2, pp. 155-183.

Pointblanknews.com (2013, August 2), "Presidency vs IOCs on oil theft: the truth is gradually coming out", Available at: http://pointblanknews.com/pbn/articlesopinions/presidency-vs-iocs-on-oil-theft-the-truth-is-gradually-coming-out/ (Accessed 3 August 2013).

Pupovac, S. and Moerman, L. (2017), “Hybrid accounts: Shell's letter to Mr and Mrs shareholder", Accounting, Auditing \& Accountability Journal, Vol. 30 No. 5, pp. 11841201.

Rhee, S.-K. and Lee, S.-Y. (2003), "Dynamic change of corporate environmental strategy: rhetoric and reality", Business Strategy and the Environment, Vol. 12 No. 3, pp. 175190.

Rouleau, L. (2005), “Micro-practices of strategic sensemaking and sensegiving: how middle managers interpret and sell change every day", Journal of Management Studies, Vol. 42 No. 7, pp. 1413-1441.

Ruffing, L. (2007), "Silent vs. Shadow reports: what can we learn from BP's sustainability report versus the financial times?" Social and Environmental Accountability Journal, Vol. 27 No. 1, pp. 9-16.

Sahara Reporters (2012, August 16), "ExxonMobil denies knowledge of source of Niger Delta's oil spill, angering residents", Available at: http://saharareporters.com/newspage/exxonmobil-denies-knowledge-source-niger-deltas-oil-spill-angering-residents (Accessed 16 August 2012).

Sahara Reporters (2015, March 15), "Nigeria: oil spill from Shell's Seibou well in Bayelsa traced to equipment failure", Available at: http://royaldutchshellplc.com/2015/03/15/nigeria-oil-spill-from-shells-seibou-wellin-bayelsa-traced-to-equipment-failure/ (Accessed 18 August 2018).

Søderberg, A. (2003), "Sensegiving and sensemaking in an integration process: A narrative approach to the study of an international acquisition", In Czarniawska, B. and Pasquale Gagliardi, P, (Eds.), Narratives We Organize By, John Benjamins Publishing Company, Amsterdam, Netherlands, pp. 3-36.

Sonenshein, S. (2010), "We're changing - or are we? Untangling the role of progressive, regressive, and stability narratives during strategic change implementation", Academy of Management Journal, Vol. 53 No. 3, pp. 477-512.

Steiner, R. (2010), Double standard: Shell practices in Nigeria compared with international standards to prevent and control pipeline oil spills and the deepwater horizon oil spill, Friends of the Earth Netherlands, Amsterdam.

Stockman, L., Rowell, A. and Kretzmann, S. (2009), "Shell's big dirty secret Insight into the world's most carbon intensive oil company and the legacy of CEO Jeroen van der Veer",

Available at 
http://www.foeeurope.org/corporates/Extractives/shellbigdirtysecret_June09.pdf (Accessed 23 February 2012).

Summerhays, K. and de Villiers, C. (2012), "Oil company annual report disclosure responses to the 2010 Gulf of Mexico oil spill", Journal of the Asia-Pacific Centre for Environmental Accountability, Vol. 18 No. 2, pp. 103-130.

The Independent (2014, November 13), "Shell was told to replace pipeline six years before oil spills", Available at: https://www.independent.co.uk/news/business/news/shell-wastold-to-replace-pipeline-six-years-before-nigeria-oil-spills-9859305.html (Accessed 18 August 2018).

The Vanguard (2015, June 6), "Oil spillage: S-Court orders Shell to pay N30m to four communities in Delta", Available at: https://www.vanguardngr.com/2015/06/oilspillage-s-court-orders-shell-to-pay-n30m-to-four-communities-in-delta/ (Accessed 18 August 2018).

Tregidga, H. (2017), "Speaking truth to power": analysing shadow reporting as a form of shadow accounting", Accounting, Auditing \& Accountability Journal, Vol. 30 No. 3, pp. 510-533

UNEP (2011), Environmental assessment of Ogoniland, United Nations Environment Programme, Nairobi, Kenya

van Halderen, M.D., Bhatt, M., Berens, G.A.J.M, Brown, T.J. and van Riel, C.B.M. (2016), "Managing impressions in the face of rising stakeholder pressures: examining oil companies' shifting stances in the climate change debate", Journal of Business Ethics, Vol. 133 No. 3, pp. 567-582.

Wehmeier, S. and Schultz, F. (2011), "Communication and corporate social responsibility: a storytelling perspective", In Ihlen O., Bartlett, J.L. and May, S. (Eds.), The handbook of communication and corporate social responsibility, John Wiley \& Sons Inc., Sussex, UK, pp. 467-488

\section{Corporate reports:}

Chevron Corporate Responsibility Reports (from 2006-2015).

Chevron Nigeria (2010), "Corporate social responsibility: people, partnership and progress", Available at: http://www.chevron.com/documents/pdf/CNL-2010-CR-report.pdf (Accessed 13 November 2011).

Chevron Nigeria (2012), "Corporate social responsibility: Chevron in Nigeria”, Available at: http://www.chevron.com/documents/pdf/corporateresponsibility/Chevron_CR_Rep ort_2012.pdf\#nameddest=pdata (Accessed 19 December 2013).

Eni Sustainaibility Report/ Performance and Eni For (from 2006-2015)

ExxonMobil Corporate Citizenship Reports (from 2006-2015)

Shell (2010), Shell letter to "Mrs and Mr"

Shell Nigeria (2011a), "Webchat- working in a complex environment: session 1 transcript.

July", Available

at:

http://www.shelldialogues.com/sites/default/files/Nigeria\%20Webchat\%20-

\%20July\%202011\%20-\%20Session\%201.pdf (Accessed 16 August 2012)

Shell Nigeria (2011b), "Webchat- working in a complex environment: session 2 transcript.

July",

Available

at:

http://www.shelldialogues.com/sites/default/files/Nigeria\%20Webchat\%20-

\%20July\%202011\%20-\%20Session\%202.pdf (Accessed 16 August 2012).

Shell Nigeria (2011c, October), "SPDC action on matters addressed in the UNEP report", 
http://www.shell.com.ng/home/content/nga/environment_society/our_response/ (Accessed 16 August 2012).

Shell Nigeria (2011d), "Environmental performance - oil spills", Available at: http://wwwstatic.shell.com/static/nga/downloads/pdfs/briefing_notes/env_perf_oilspills.pdf (Accessed 5 November 2011).

Shell Nigeria (2011e), "Environmental performance - oil spills", Available at: http://wwwstatic.shell.com/static/nga/downloads/pdfs/briefing_notes/env_perf_oilspills.pdf (Accessed 5 November 2011).

Shell Nigeria Annual report 2006: "People and the environment", Available at: http://narcosphere.narconews.com/userfiles/70/2006_shell_nigeria_report.pdf (Accessed 20 November 2011).

Shell Sustainability Reports (from 2006-2015)

Total Environment and Society/ Total Sustainable Growth/ Total Global Compact (from 20062015)

Total Upstream Nigeria Corporate Social Responsibility Report (2007, 2008 \& 2009)

Total Upstream Nigeria (2009, July 20), “Address by Deputy Managing Director Total E\&P Nigeria, Roger Poirier", Available at: http://www.ng.total.com/media/speeches/2009-DMD_T_HOR-Ctee-on-Petroleumvisit.pdf (Accessed 5 October 2011)

Table 1: Number of oil spill incidents in Nigeria from $2001-2016$

\begin{tabular}{|c|c|}
\hline Year & No of spill incidents \\
\hline 2001 & $412^{*}$ \\
\hline 2002 & $446^{*}$ \\
\hline 2003 & $609^{*}$ \\
\hline 2004 & $543^{*}$ \\
\hline 2005 & $496^{*}$ \\
\hline 2006 & $461^{*}$ \\
\hline 2007 & $482^{*}$ \\
\hline 2008 & $740^{*}$ \\
\hline 2009 & $849^{*}$ \\
\hline 2010 & $537^{\wedge}$ \\
\hline 2011 & $673^{* \wedge}$ \\
\hline 2012 & $844^{\wedge}$ \\
\hline 2013 & $522^{\wedge}$ \\
\hline 2014 & $1,087^{\wedge}$ \\
\hline 2015 & $753^{\wedge}$ \\
\hline 2016 & $434^{\wedge}$ \\
\hline
\end{tabular}

Source: * Data provided by DPR, Lagos (February 16, 2012)

^DPR Oil \& Gas Annual Report 2016, p. 82 (Accessed August 8, 2018)

Table 2: A summary of reports analysed in the selected MNCs

\begin{tabular}{|c|c|c|c|}
\hline MNCs & Global CSR & $\begin{array}{c}\text { Subsidiary } \\
\text { CSR \& others }\end{array}$ & Aggregate \\
\hline
\end{tabular}




\begin{tabular}{|c|c|c|c|}
\hline Chevron & 10 & 2 & 12 \\
\hline Eni & 10 & 0 & 10 \\
\hline ExxonMobil & 10 & 0 & 10 \\
\hline Shell & 10 & 7 & 17 \\
\hline Total & 10 & 4 & 14 \\
\hline Aggregate & 50 & 13 & 63 \\
\hline
\end{tabular}

